\title{
ASSESSMENT OF NUCLEAR TOTIPOTENCY OF FETAL BOVINE DIPLOID GERM CELLS BY NUCLEAR TRANSFER
}

\author{
A. Moens, ${ }^{1,2}$ P. Chesné, ${ }^{1}$ F. Delhaise, ${ }^{2}$ A. Delval, ${ }^{3}$ F-J. Ectors, ${ }^{3}$ F. Dessy, ${ }^{2}$ J-P. Renard ${ }^{1}$ \\ and Y. Heyman ${ }^{1 a}$ \\ ${ }^{1}$ Unité de Biologie du Développement, INRA, Jouy-en-Josas Cedex 78352, France \\ ${ }^{2}$ Unité des Sciences Vétérinaires, Université catholique de Louvain, Belgium \\ ${ }^{3}$ Centre de Recherche IRSIA-CERAD, Faculté de Médecine Vétérinaire, Liège, Belgium
}

\author{
Received for publication: October 9, 1995 \\ Accepted: January 15, 1996
}

\begin{abstract}
Nuclear transfer was used to study nuclear reprogramming of fetal diploid bovine germ cells collected at two stages of the fetal development. In the first case, germ cells of both sexes were collected during their period of intragonadal mitotic multiplication at 48 days post coïtum (d.p.c.). In the second case, only male germ cells were collected after this period, between 105 and 185 d.p.c. Isolated germ cells were fused with enucleated oocytes. Reconstituted embryos were cultured in vitro and those reaching the compacted morula or blastocyst stage were transferred into synchronous recipient heifers. Of 511 reconstituted embryos with 48 d.p.c. germ cells ( 309 males and 202 females), $48 \%(247 / 511)$ cleaved; $2.7 \%(14 / 511)$ reached the compacted morula stage and 8 of them the blastocyst stage $(1.6 \%)$. No difference was observed between sexes. All 14 compacted morulae/blastocysts were transferred into 6 recipients and one pregnancy was initiated. This recipient was slaughtered at Day 35 and an abnormal conceptus (extended trophectoderm and degenerated embryo) was collected. Its male sex, genetically determined, corresponded to that of donor fetus. Of 380 reconstituted embryos with male 105 to 185 d.p.c. germ cells, $72.1 \%(274 / 380)$ cleaved, $2.1 \%(8 / 380)$ reached the compact morula stage and 7 of these the blastocyst stage $(1.8 \%)$. Three blastocysts and one morula were transferred into 4 recipients. Two became pregnant at Day 21 but only one at Day 35 which aborted around Day 40 . Our results show that the nucleus of diploid bovine germ cells of both sexes can be reprogrammed. However, in the absence of further development of these reconstituted embryos, nuclear totipotency of bovine diploid germ cells remains to be evidenced.
\end{abstract}

Key words: nuclear transfer, cattle, diploid germ cells, nuclear totipotency

\section{Acknowledgments}

This work was supported in part by a grant from Rhone-Mérieux and the French ministry of Research, by the E.U. Biotechnology project BIO-2 CT 92-0067, by the Belgian FRMS contract 3.4609.95, the Belgian IRSIA contract $9761 / 5597 \mathrm{~A}$. We also thank Dr R. De Roover, N. Schuurbiers, V. Bralion and P. Bombaerts for their technical assistance.

aCorresponding author. 


\section{INTRODUCTION}

In the frog (Rana pipiens), the tail bud-stage is the latest developmental stage from which a tadpole has been produced by nuclear transfer of a somatic nucleus, whereas $40 \%$ of germ cell nuclei of this stage are still totipotent (34). Lesimple et al. (23) obtained normal adults by nuclear transfer of germ cells isolated from larva of salamanders (Pleurodeles waltl). In amphibians, germ cells seem to retain their nuclear totipotency longer than somatic differentiated cells (12).

In mammals, primordial germ cells (PGC) migrate from the mesoderm surrounding the hind gut to reach the undifferentiated gonad. In several species (cattle, sheep, pig, rabbit) these germ cells continue to multiply while the gonads (testes or ovaries) begin to differentiate (4). If these germ cells are still totipotent, they could be an important source of nuclei for nuclear transfer, especially in domestic species. Furthermore, all these cells isolated from the same gonad have the same genetic characteristics.

Nuclear totipotency can be evidenced by nuclear transfer. In mammals, only nuclei from preimplantation embryos (16-32-cell-stage embryo or the ICM of a blastocyst) have been shown to remain totipotent. This is also the case for rabbits ( 9 , $15,36)$, sheep $(5,35,38)$, pigs (29), goats (39) and cattle $(1,3,6,13,16,20)$.

Nuclear totipotency of PGC was first evaluated in the mouse species (37) where blastocysts were obtained after nuclear transfer of male germ cells. More recently it has been shown that blastomeres isolated from a mouse preimplantation embryo that was reconstituted with male diploid germ cell can differentiate when introduced into a normal embryo (19). In the rabbit, our previous experiments demonstrated the ability of fetal germ cell nuclei of both sexes to control preimplantation development $(26,27)$.

In cattle, meiosis starts in the differentiating fetal ovary at 65 to 80 d.p.c. $(14,32)$. This phenomenon of delayed meiosis (opposed to immediate meiosis as observed in the mouse) also occurs in rabbits, sheep and pigs $(4,24)$. In these species, at the time that meiosis starts in the female, the mitotic activity in the male germ cells decreases (4), as examplified by the bovine (18). We were interested to study nuclear totipotency of diploid bovine germ cells at 2 stages of their fetal development: 1) when germ cells of both sexes display high mitotic activity ( 35 to $65-80$ d.p.c.) and 2 ) in the male after this period ( $>100$ d.p.c.) when the mitotic activity of germ cells is reduced.

We assessed the possibility of reprogramming the nucleus of bovine diploid fetal germ cells by studying the in vitro development of embryos reconstituted by nuclear transfer. Their nuclear totipotency was tested in vivo after the transfer of these embryos into recipient heifers. In this work we assumed that nuclear reprogramming is the possibility for a nucleus transferred into a competent enucleated oocyte to control the preimplantation development; furthermore, nuclear totipotency is the ability of a nucleus to support the whole of embryonic and fetal development. 


\section{MATERIALS AND METHODS}

\section{Isolation and Selection of Germ Cells}

To obtain 48 d.p.c. diploid germ cells before meiosis, 10 cows were artificially inseminated. Ultrasonography was performed at Day 35 p.c., and 7 pregnant females were slaughtered at 48 d.p.c. Fetuses were collected aseptically and classified as male or female by macroscopical examination. Gonads were dissected, washed twice in phosphate buffered saline (PBS), and cut into 2 to 3 small pieces. The remaining part of each fetus was stored at $-80^{\circ} \mathrm{C}$ for confirmation of their sex by a DNA analysis using a $Y$-specific probe (see below). Pieces of the fetal gonads were enzymatically digested by an incubation in $1 \mathrm{ml}$ of $0.125 \%\left(\mathrm{w} / \mathrm{v}\right.$ ) trypsin (Sigma Chemical, St. Louis, MO; Cat $\mathrm{n}^{\circ}$ $\mathrm{T}-1005), 0.025 \%(\mathrm{w} / \mathrm{v})$ collagenase (Sigma; Cat $\left.\mathrm{n}^{\circ} \mathrm{C}-9407\right)$, and $0.2 \%(\mathrm{v} / \mathrm{v})$ DNAse (20 $\mathrm{U} / \mathrm{ml}$; Sigma; Cat $\mathrm{n}^{\circ} \mathrm{DN}-25$ ) in a Tris-buffered solution, $\mathrm{pH} 7.2$ at $35^{\circ} \mathrm{C}$ (warm plate) for $20 \mathrm{~min}$ for fetal ovaries and $30 \mathrm{~min}$ for fetal testis. Digestion was stopped by addition of $0.5 \mathrm{ml}$ of noninactivated fetal calf serum (FCS; Biosys-France, Compiegne; batch 250165 ) after which the pieces were transferred into $1 \mathrm{ml}$ of PBS supplemented with $33 \%$ of inactivated FCS.

Older male germ cells were prepared from fetuses collected at random at a slaugtherhouse, and their approximative age was evaluated on the basis of their crowrump length $(18,30,32)$. Only cells from 105 to 185 d.p.c. were used. Gonads were dissected, washed twice in PBS and cut into 2 to 3 small pieces, and then incubated for $30 \mathrm{~min}$ in a mixture of dispase $1.2 \mathrm{U} / \mathrm{ml}$ (Sigma; Cat $\left.\mathrm{n}^{\circ} \mathrm{P}-3417\right)+$ collagenase $0.01 \%$ (Sigma; Cat $\left.\mathrm{n}^{\circ} \mathrm{C}-9407\right)+$ DNAse $20 \mathrm{U} / \mathrm{ml}$ (Sigma; Cat $\mathrm{n}^{\circ} \mathrm{DN}-25$ ) at $39^{\circ} \mathrm{C}$. After mechanical dissociation, the cells were centrifuged at $170 \times \mathrm{g}$ and resuspended in DMEM/F12 (Life Technologies, Inc., Grand Island, NY, USA; Cat n $\left.{ }^{\circ} 074-02500\right)+10 \%$ FCS (Life Technologies; Cat $\mathrm{n}^{\circ} 10084-069$ ) $+10 \%$ newborn calf serum (Life Technologies; Cat $\left.n^{\circ} 16010-076\right)+10^{-4}$ M B-mercaptoethanol (Sigma; Cat $n^{\circ}$ M-7522).

In both cases, a $0.2 \mathrm{ml}$-drop of the gonadal cells suspension was transferred to a bacteriological dish under silicone oil (Sigma; Cat $n^{\circ} \mathrm{M}-3516$ ). Germ cells were selected one at a time with a Leitz micromanipulor on the basis of their particular morphology: large yellowish irregular-shape cells displaying a large nucleus and pseudopods (22). They were kept into a $50 \mu \mathrm{l}$-drop of micromanipulation medium at $39^{\circ} \mathrm{C}$ for $2 \mathrm{~h}(48$ d.p.c. PCG) or up to $20 \mathrm{~h}$ (105 to 185 d.p.c. PGC) until fusion.

\section{Nuclear Transfer and Culture}

A similar protocol of nuclear transfer has been used in France (6) and Belgium (13). After $24 \mathrm{~h}$ maturation oocytes were enucleated by micromanipulation, cultured for another 10 to $12 \mathrm{~h}$ and then kept at $10^{\circ} \mathrm{C}$ for $\pm 10 \mathrm{~h}$ before reconstitution with germ cells. Sclccted germ cclls were placed in the micromanipulation medium (basic medium 199 [Life Technologies; Cat $n^{\circ}$ 071-01100A] supplemented with $20 \mathrm{mM}$ HEPES [Sigma; Cat $\mathrm{n}^{\circ} \mathrm{H}-3375$ ]) and $10 \%$ inactivated FCS with the enucleated oocytes. One germ cell was carefully inserted into the perivitelline space of each recipient oocyte using a fine-glass micropipette controlled by a micromanipulator. Reconstituted embryos were transferred into a $0.3 \mathrm{ml}$-drop of fusion medium [aqueous solution of 0.3 M mannitol, $\left.100 \mu \mathrm{M} \mathrm{Mg}^{++}\left(\mathrm{MgCl}_{2}\right), 100 \mu \mathrm{M} \mathrm{Ca}^{++}\left(\mathrm{CaCl}_{2}\right)\right]$ for equilibration for $5 \mathrm{~min}$ and placed between electrodes. Fusion was achieved by 2 DC pulses of $1.3 \mathrm{kV} / \mathrm{cm}$ for 
$50 \mu$ s before being co-cultured for 6 to $7 \mathrm{~d}$ at $39^{\circ} \mathrm{C}$ on a monolayer of oviductal cells in B2 medium (BioMérieux, France) supplemented with $10 \%(\mathrm{v} / \mathrm{v})$ heat-inactivated FCS. Since it is difficult to record the fusion rate, we only evaluated the cleavage rate of the reconstituted embryos after $48 \mathrm{~h}$ of culture. The compacted morula rate was recorded after $6 \mathrm{~d}$, while the expanded blastocyst rate after 7 to $8 \mathrm{~d}$ of culture.

\section{Cell Number Determination}

When no synchronous recipient was available, some reconstituted blastocysts were fixed for $1 \mathrm{~h}$ in a $2.5 \%$ paraformaldehyde solution, rinsed in PBS, stained with Hoescht dye $\mathrm{n}^{\circ} 33342(10 \mu \mathrm{g} / \mathrm{ml})$ for $15 \mathrm{~min}$ and observed under fluorescence microscopy (UV light) for nuclei counting.

\section{In Vivo Transplantation}

Compacted morulae or expanded blastocysts were transplanted into synchronized recipient heifers. Initiation of pregnancy was assessed by the progesterone blood level at Day $21(\geq 5-6 \mathrm{ng} / \mathrm{ml}$ ), by PAG (Pregnancy Associated Glycoprotein) blood level at Days 30 or 35, according to Zoli et al. (40). A level of $\geq 4$ $\mathrm{ng} / \mathrm{ml}$ was considered as positive. An ultrasonographic examination was also performed at Day 35. One pregnant recipient was slaughtered at Day 35 to examine the development of the conceptus.

\section{Genetic Determination of Sex}

Donor fetuses of 48 d.p.c. were genetically sexed to confirm their morphological sex. For this genetic determination, DNA from a $100-\mathrm{mg}$ piece of each donor fetus was extracted (33). Specific sequences of bovine $Y$-chromosome were amplified according to Perret et al. (28). Each sample of DNA was amplified 2 times, and 3 different controls were systematically used: male, female and blank (no DNA). After migration on a $1 \%$ agarose gel, PCR amplification products were stained with ethidium bromide and visualised under UV light. The same technique, which has a $99 \%$ accuracy (28), was applied to the degenerated conceptus recovered from a recipient at Day 35 to compare its sex with that of donor fetus.

\section{Statistical Analysis}

Rates of cleavage and development to morula and blastocysts were analysed using Chi-square test.

\section{RESULTS}

\section{Morphological Aspects of Isolated Germ Cells}

When isolated from the gonad at 48 d.p.c, bovine germ cells morphology is very similar to that of rabbit fetal germ cell $(26,27)$ or mouse primordial germ cells $(2,10)$. They are large cells of 12 to $15 \mu \mathrm{m}$ diameter, with a smooth cell surface, a large nucleus with 2 or 3 dark nucleoli and scarce cytoplasm (22). After isolation, they display a characteristic pseudopodial activity also observed in rabbit fetal germ cells and mouse primordial germ cells. No morphological difference was observed between male and 
female germ cells at this stage of fetal development. Moreover, we noticed no morphological difference between male germ cells isolated from 105 to 185 d.p.c. fetuses and germ cells isolated from 48 d.p.c. fetuses.

\section{In Vitro Development of Reconstituted Embryos}

In the first experiment, a total of 511 embryos was reconstituted with 48 d.p.c. germ cells, in 4 replicates ( 309 with male germ cells and 202 with female germ cells). Of 511 embryos, 247 cleaved ( 2 to 4 cells; 157 males and 90 females), 14 developed into compacted morulae ( 9 males and 5 females), from which 8 reached the expanded blastocyst stage ( 5 males and 3 females). Between sexes, no difference was observed for the cleavage rate: male $50.8 \%(157 / 309)$; female $44.5 \%(90 / 202)$, or for the compacted morulae rate: male $2.9 \%(9 / 309)$; female $2.5 \%(5 / 202)$, or for the expanded blastocysts rate: male $1.6 \%(5 / 309)$; female $1.5 \%(3 / 202)$. Results are shown below (Table 1 ).

Table 1. In vitro development of embryos reconstituted with 48 days post coitum germ cells

\begin{tabular}{|c|c|c|c|c|c|}
\hline \multicolumn{2}{|c|}{ Germ cells } & \multicolumn{4}{|c|}{ Reconstituted embryos } \\
\hline Sex & Age p.c. & Reconstituted & 2 to 4 cell & Morula & Blastocysts \\
\hline male & 48 & 309 & $157(50.8 \%)$ & $9(2.9 \%)$ & $5(1.6 \%)$ \\
\hline female & 48 & 202 & $90(44.5 \%)$ & $5(2.5 \%)$ & $3(1.5 \%)$ \\
\hline \multicolumn{2}{|c|}{ Total } & 511 & $247(48.3 \%)$ & $14(2.7 \%)$ & $8(1.6 \%)$ \\
\hline
\end{tabular}

Within column, percentages are not significantly different $(\mathrm{P}>0.05)$.

In the second experiment (Table 2), of the 380 reconstituted embryos with male diploid germ cells isolated from 105 to 185 d.p.c. fetuses, $72.1 \%(274 / 380)$ cleaved, $2.1 \%$ $(8 / 380)$ developed up to the compacted morula stage and most of them $(7 / 8)$ up to the expanded blastocyst stage $(1.8 \%)$. No different cleavage rates were observed between male germ cells of different ages. Too few morulae and blastocysts were obtained for a statistical analysis. Of 8 morula/blastocysts, 4 ( 3 blastocysts and 1 morula) were transplanted into 4 synchronous foster mothers. The 4 remaining morulae/blastocysts were fixed at Day 7 post fusion and their cell numbers (assessed by nuclei counting) were, respectively, 66, 76,90 and 135 cells (mean $=92 \pm 15$ ). The results of development of the reconstituted embryos with 175 d.p.c.germ cells were presented in part in a short communication (11).

Table 2. In vitro development of embryos reconstituted with 105 to 185 days post coitum germ cells

\begin{tabular}{|c|c|c|c|c|c|c|}
\hline \multicolumn{2}{|c|}{ Germ cells } & \multicolumn{5}{|c|}{ Reconstituted embryos } \\
\hline Sex & Age p.c. & Reconstituted & $2-4$ cell $^{a}$ & Morula & Blastocysts & Cell no. \\
\hline male & 105 & 87 & $61(70.0 \%)$ & $1(1.1 \%)$ & $1(1.1 \%)$ & 66 \\
\hline male & $145-155$ & 103 & $77(74.7 \%)$ & 0 & 0 & - \\
\hline male & 175 & 115 & $79(68.7 \%)$ & $6(5.2 \%)$ & $5(4.3 \%)$ & $76,90,135$ \\
\hline intale & 185 & 75 & $57(76.0 \%)$ & $1(1.3 \%)$ & $1(1.3 \%)$ & n.d. \\
\hline \multicolumn{2}{|c|}{ Total } & 380 & $274(72.1 \%)$ & $8(2.1 \%)$ & $7(1.8 \%)$ & $\overline{\bar{x}}=\overline{92 \pm 15}$ \\
\hline
\end{tabular}

a Within column, percentages are not significantly different $(\mathrm{P}>0.05)$. 
In Vivo Development of Reconstituted Embryos

In the first experiment, the compacted morulae and blastocysts obtained from a single 48 d.p.c. old fetus were transplanted in a single recipient. Results are presented in Table 3. Of 6 recipients, 1 (no. B88) was found presumed pregnant at Day 21 by progesterone assay, and was positive for PAG on Day 30. Ultrasonographic examination on Day 35 revealed the presence of some fluid inside the uterus. The recipient was slaugthered at Day 35 and a conceptus consisting of an extended trophectoderm and a degenerated embryo was collected. No morphological signs of implantation were observed despite the presence of a well-developed corpus luteum. Male sex of this conceptus was genetically assessed and it corresponded to that of germ cells used in this experiment.

Table 3. In vivo development of embryos reconstituted with 48 days post coitum germ cells

\begin{tabular}{|c|c|c|c|c|c|}
\hline Embryos & & \multicolumn{3}{|c|}{ Recipients } & Results \\
\hline $\begin{array}{c}\text { Number and stage } \\
\text { (sex) }\end{array}$ & $\begin{array}{l}\text { ID } \\
\text { no. }\end{array}$ & $\begin{array}{c}\text { Proges } \\
21\end{array}$ & $\begin{array}{c}\mathrm{PAG} \\
30\end{array}$ & $\begin{array}{l}\text { Ultras } \\
35\end{array}$ & Conceptuses \\
\hline 1 blastocyst +2 morulac (M) & B88 & + & + & + & 1 (degenerated) \\
\hline 1 blastocyst +1 morula (M) & B91 & - & - & - & - \\
\hline 1 blastocyst +1 morula (M) & B105 & - & - & - & - \\
\hline 2 blastocysts +1 morula $(F)$ & B111 & - & - & - & - \\
\hline 2 blastocysts $(\mathrm{F})$ & B112 & - & - & - & - \\
\hline 1 blastocyst +1 morula (M) & B113 & - & - & - & - \\
\hline Total $9(\mathrm{M})+5(\mathrm{~F})$ & 6 & 1 & 1 & 1 & 1 (degenerated) \\
\hline
\end{tabular}

M: male; F: female; Proges 21: blood progesterone at Day 21 p.c.; PAG: blood pregnancy associated glycoprotein at Day 30 p.c.; Ultras: ultrasound examination at Day 35 p.c.

In the second experiment (Table 4), of the 4 recipients which received embryos reconstituted with 105 to $185 \mathrm{dpc}$ male germ cells, pregnancy was initiated in Nos. 009 and 7719 on the basis of the level of blood progesterone at Day 21. One recipient was still pregnant on the basis of the PAG level at Day 35. The PAG blood level began to decrease from Day 35 to Day 40, suggesting an abortion. No attempt was made to collect the conceptus.

Table 4. In vivo development of embryos reconstituted with 105 to 185 days post coitum germ cells

\begin{tabular}{|c|c|c|c|c|c|}
\hline Embryos & & \multicolumn{3}{|c|}{ Recipients } & Results \\
\hline $\begin{array}{l}\text { Number and stage } \\
\text { (sex) }\end{array}$ & $\begin{array}{l}\text { ID } \\
\text { no. }\end{array}$ & $\begin{array}{c}\text { Proges } \\
21\end{array}$ & $\begin{array}{c}\text { PAG } \\
35\end{array}$ & $\begin{array}{c}\text { Ultras } \\
35\end{array}$ & Conceptuses \\
\hline 1 blastocyst $(\mathrm{M})$ & 009 & + & + & n.d. & - \\
\hline 1 blastocyst $(M)$ & 2878 & - & - & n.d. & - \\
\hline 1 blastocyst $(M)$ & 2179 & - & - & n.d. & - \\
\hline 1 morula $(\mathrm{M})$ & 7719 & + & - & - & - \\
\hline Total $\quad 4(\mathrm{M})$ & 4 & $\overline{2}$ & $\overline{1}$ & $\overline{0}$ & - \\
\hline
\end{tabular}

M: male; F: female; Proges 21: blood progesterone at Day 21 p.c.; PAG: blood pregnancy associated protein at Day 35 p.c.; Ultras: ultrasound examination at Day 35 p.c. 


\section{DISCUSSION}

In cattle, migrating primordial germ cells reach genital ridges around Day 35 p.c. (18), and continue to multiply mitotically in the differentiating fetal gonad until Day 65 to 80 d.p.c. At this stage, the first signs of meiosis can be observed in the female (14, 32). In the male, after an initial phase of a intragonadal multiplication, the rate of mitotic divisions of germ cells seems to decrease (4), as described in sheep (17), while in rodents, the male germ cells enter in quiescence at the time of testicular differentiation (4).

Our morphological observations suggest that these male germ cells undergo no morphological differentiation between 48 and 185 d.p.c and that these cells could be a good potential source of diploid nuclei for nuclear transfer. However, such a morphological characterization first needs to be completed by functional and molecular characterization.

Our results show that the nucleus of diploid male and female bovine fetal germ cells can be reprogrammed by nuclear transfer and can control embryonic development up to the blastocyst stage. Germ cells of both sexes isolated during the period of intragonadal multiplication ( 48 d.p.c.) have a similar ability to be reprogrammed since no differences between sexes were noticed throughout early development in vitro. However, it should be noted that the cleavage rate of embryos reconstituted with 105 to 185 d.p.c. male germ cells was higher than the cleavage rate of those reconstituted with 48 d.p.c. germ cells (respectively 72 vs $48 \%$ ). Since nuclear transfer efficiency was similar in both laboratories when blastomeres were used as donor nuclei $(23.7$ and $23.8 \%$ blastocysts, respectively), the better cleavage rate resulting from 105 to 185 d.p.c male germ cells is probably related to the age at which these cells were prepared. The nucleus of 105 to 185 d.p.c. germ cells may allow for better synchronization with recipient cytoplasts. These male germ cells are essentially characterized by a decrease in the multiplication rate, which increases the proportion of cells at the G1 phase. The G1 nuclei are thought to be the best candidates for nuclear transfer into an enucleated oocyte (8). The nucleus of a germ cell isolated from 105 to 185 d.p.c. male fetuses could be more adapted to nuclear transfer than that from a germ cell isolated at $48 \mathrm{~d} . \mathrm{p} . \mathrm{c}$.

In the present work, the rate of blastocyst derived from germ cells nuclear transfer was low (48 d.p.c.: $1.6 \%, 105$ to 185 d.p.c.: $1.8 \%$ ) compared with that obtained after nuclear transfer of bovine blastomeres at the 32 to 64 -cell stage in the same laboratories $(6,13)$. Blastocysts have also been produced by nuclear transfer of differentiated somatic cells such as granulosa cells (7, Lavoir, personal communication), fetal fibroblasts (7) and thymocytes (21). However, until now, every attempt to produce normal fetuses after transplantation of the reconstituted embryos into recipient animals has failed. This suggests that the nucleus of several types of somatic differentiated cells can be reprogrammed by nuclear transfer but is unable to control peri- and post-implantation development, and therefore cannot be qualified as totipotent.

The fetal germ cell is considered to be a highly differentiated cell $(25,31)$ and, as a consequence, its nucleus would not be totipotent. However, mouse blastocysts were obtained after nuclear transfer of male fetal germ cells (37). Moreover, Kato and Tsunoda (19) demonstrated nuclear pluripotency of mouse male fetal germ cells. They 
produced 2-cell stage mouse embryos after nuclear transfer of male fetal germ cells. The nucleus of a 2-cell blastomere reconstituted embryo was transferred into an enucleated blastomere of a normal 2-cell embryo. The chimeric embryos were transplanted into recipients and 10.5 to $12.5-\mathrm{d}$ chimeric conceptuses were obtained. These results show the possible reprogramming of the nucleus of fetal male germ cell in the mouse as well as of its nuclear pluripotency, but this nucleus still cannot be considered as totipotent. To date, only nuclei of cells isolated from preimplantation embryos have been shown to be totipotent in various mammalian species (rabbits, cattle, sheep, goats, from which offspring were obtained.

In our experiments, in vivo development of the bovine embryos derived from nuclear transfer of germ cells ended before or at the peri-implantation period. Of 14 reconstituted compact morulae and blastocysts transferred into recipient heifers, none resulted in a live fetus. This suggests that the nucleus of bovine fetal germ cells is not totipotent. This is consistent with our results in the rabbit, in which no implantation site was observed after the transplantation of 135 embryos reconstituted with male or female diploid fetal germ cells (27). However, we have also to consider the possibility that a too low number of reconstituted morula/blastocysts was transplanted into the recipient. Additional transplantations into recipient cows should clarify the point before drawing conclusions on the lack of totipotency of bovine germ cells.

The reason for the absence of peri- and post-implantation development of our reconstituted bovine embryos is not known. Besides the limited number of recipients used, one possible explanation could be the loss of appropriate imprints in germ cells. This would mean that some parental imprints required for the implantation are already erased in the germ line at 48 d.p.c. or (and) that some fetal imprints are already in place. Another possibility may be that diploid germ cells isolated from the fetal gonad are already differentiated. To be used as a source of totipotent nuclei, these germ cells need have been cultured in vitro and to have undergone a process of "dedifferentiation" to come back to an undifferentiated status, as suggested by Rossant (31) apropos mouse embryonic germ (EG) cells.

Very little has been known about the process of reprogramming at the molecular level (i.e., gene expression, imprinting, epigenetic effects). Without this fundamental knowledge, it will be difficult to improve the efficiency of the nuclear transfer technology using germ cells as the source of nuclei.

\section{REFERENCES}

1. Barnes FL, Endebrock M, Looney C, Powell R, Westhusin M, Bondioli K. Embryo cloning in cattle: the use of in vitro matured oocytes. J Reprod Fertil 1993; 97: 317320.

2. Blandau RJ, White BJ, Rumery RE. Observations of the movements of the living primordial germ cells in the mouse. Fertil Steril 1963; 14: 483-489.

3. Bondioli KR, Westhusin ME, Looney CR. Production of identical bovine offspring by nuclear transfer. Theriogenology 1990; 33: 165-173.

4. Byskov AG, Hoyer PE. Embryology of mammalian gonads and ducts. In Knobil E,Neil JD (eds), The Physiology of Reproduction. New York: Raven Press, 1994, 487-540. 
5. Campbell KHS, Loi P, Cappai P, Wilmut I. Improved development to blastocyst of ovine nuclear transfer embryos reconstructed during the presumptive S-phase of anucleated activated oocytes. Biol Reprod 1994; 50: 1385-1393.

6. Chesne P, Heyman Y, Peynot N, Renard JP. Nuclear transfer in cattle: birth of cloned calves and estimation of blastomere totipotency in morulae used as a source of nuclei. CR Acad Sci (Paris), Sciences de la vie 1993; 316: 487-491.

7. Collas P, Barnes FL. Nuclear transplantation by microinjection of inner cell mass and granulosa cell nuclei. Mol Reprod Dev 1994; 38: 264-267.

8. Collas P, Balise JJ, Robl JM. Influence of cell cycle stage of the donor nucleus on development of nuclear transplant rabbit embryos. Biol Reprod 1992; 46: 492-500.

9. Collas P, Robl M. Factors affecting the efficiency of nuclear transplantation in the rabbit embryo. Bio Reprod 1990; 43: 877-884.

10. De Felici M, Dolci S, Pesce M. Cellular and molecular aspects of mouse primordial germ cell migration and proliferation in culture. Int J Dev Biol 1992; 36: 205-213.

11. Delhaise F, Ectors FJ, De Roover R, Ectors F and Dessy F. Nuclear transplantation using bovine primordial germ cells from male fetuses. Reprod Fertil Dev, 1995; 7:1217-1219.

12. Di Bernardino MA. Genomic potential of differentiated cells analysed by nuclear transplantation. Am Zool 1987; 27: 623-644.

13 Ectors FJ, Delval A, Touati K, Thonon F, Beckers JF, Ectors F. Clonage par greffe de blastomère : naissance du premier veau. Ann Méd Vét 1993; 137: 573-574.

14. Erickson BH. Development and radio-response of the prenatal bovine embryo. J Reprod Fertil 1966; 10: 97-105.

15. Heyman $Y$, Chesné $P$, Renard JP. Reprogrammation complète des noyaux embryonnaires congelés, après transfert nucléaire chez le lapin. C R Acad Sci (Paris). 1990; 311: 321-326.

16. Heyman $Y$, Chesne P, Lebourhis D, Peynot N, Renard JP. Developmental ability of bovine embryos after nuclear transfer based on the nuclear source: in vivo versus in vitro. Theriogenology $1994 ; 42 ; 695-702$.

17. Hochereau-de Reviers MT, Perreau C, Pisselet C, Locatelli A, Bosc M. Ontogenesis of somatic and germ cells in sheep fetal testis. J Reprod Fertil 1995, 103: $41-46$.

18. Jost A, Prépin J. Données sur la migration des cellules germinales primordiales du foetus de veau. Arch Anat Microsc Morphol Exp 1966; 55: 161-186.

19. Kato $Y$, Tsunoda $Y$. Germ cell nuclei of male fetal mice can support development of chimeras to midgestation following serial transplantation. Development 1995: 121: 779-783.

20. Keefer CL, Stice SL, Matthews DL. Bovine inner cell mass cells as donor nuclei in the production of nuclear transfer embryos and calves. Biol Reprod 1994; 50: 935 939.

21. Kono T, Ogawa M, Nakahara T. Thymocyte transfer to enucleated oocytes in the mouse. J Reprod Dev 1993; 39: 301-307.

22. Lavoir MC, Basrur P.K, Betteridge KJ. Isolation and identification of germ cells from fetal bovine ovaries. Mol Reprod Dev 1994; 37: 413-424.

23. Lesimple $M$, Dournon $C$, Labrousse $M$, Houillon C. Production of fertile salamanders by transfer of germ cell nuclei into eggs. Development 1987; 100: 471477.

24. Mauléon P. Différenciation et évolution des cellules sexuelles. 2. La lignée femelle. Arch Anat Microsc 1967; 56 (Suppl): 125-150.

25. McLaren A. The quest of immortality. Nature 1992; 359: 482-483. 
26. Moens A, Chastant S, Chesné P, Betteridge KJ, Renard JP. Nuclear transfer using gonia from male rabbit fetuses. Theriogenology 1995; 43:283 abstr.

27. Moens A, Chastant S, Chesné P, Betteridge KJ, Renard JP. Differential reprogramming capabilities of male and female rabbit fetal gonadal cells. Proc Cong Eur Dev Biol Organ 1995; H6: 98.

28. Perret J, Grisart B, Georges M, Dessy F, Vassart G. Rapid, simple and sensitive sex determination of bovine embryos by PCR. Anim Genet 1996; (submitted)

29. Prather RS, Sims MM, First NL. Nuclear transplantation in pig embryos. Biol Reprod 1989; 37: 859-866.

30. Prépin J, Vigier B, Jost A. Croissance du foetus de veau de grossesse simple et multiple à l'époque de la différentiation sexuelle. Ann Biol Anim Biochim Biophys 1972; 12: 545-558.

31. Rossant J. Immortal germ cells. Curr Biol 1993; 3: 47-49.

32. Rüsse I. Oogenesis in cattle and sheep. Bibl Anat 1983; 24: 77-92.

33. Sambrook J, Fritsch EF, Maniatis T. Molecular Cloning. New York: Cold Spring Harbor Laboratory Press, 1989; E3-E4.

34. Smith LD. Transplantation of the nuclei of primordial germ cells into enucleated eggs of Rana pipiens. Proc Natl Acad Sci (USA) 1965; 54: 101-107.

35. Smith LC, Wilmut I. Influence of nuclear and cytoplasmic activity on the development in vivo of sheep embryos after nuclear transplantation. Biol Reprod 1989; 40: 1027-1035.

36. Stice S, Robl JM. Nuclear reprogramming in nuclear transplant rabbit embryos. Biol Reprod 1988; 39: 657-664.

37. Tsunoda Y, Kato Y, O'Neill GT. Cytogenetic analysis of reconstituted one-cell mouse embryos derived from nuclear transfer of male fetal germ cells. J Reprod Fertil 1992; 96: 275-281.

38. Willadsen SM. Nuclear transplantation in sheep embryos. Nature 1986; 320: 63-65.

39. Yong $Z$, Jianchen $W$, Jufen $Q$, Zhiming $H$. Nuclear transplantation in goats. Theriogenology 1991; 35: 299 abstr.

40. Zoli AP, Beckers JF, Wouters-Ballman P, Closset J, Falmagne P, Ectors F. Purification and characterization of a bovine pregnancy-associated glycoprotein. Biol Reprod 1991; 45: 1-10. 